\title{
Small Dense Low Density lipoprotein Sebagai Prediktor Risiko Penyakit Jantung Koroner pada Anak Lelaki Obes Pra-Pubertal
}

\author{
Aryono Hendarto \\ Departemen Ilmu Kesehatan Anak FK Universitas Indonesia/RS Dr. Cipto Mangunkusumo, Jakarta
}

\begin{abstract}
Latar belakang. Meningkatnya prevales obesitas pada anak menyebabkan meningkatnya komorbiditas akibat penyakit lain, salah satunya adalah penyakit kardiovaskular. Penyakit kardiovaskular merupakan salah satu penyakit penyebab kematian yang penting. Small Dense LDL (sdLDL) pada obesitas dewasa terbukti dapat dijadikan prediktor risiko penyakit jantung koroner. Penelitian serupa pada obesitas anak belum pernah dilakukan.

Tujuan. Mengetahui faktor risiko PJK pada obesitas anak dengan menggunakan sdLDL, serta kaitan adipositokin dengan timbulnya faktor risiko penyakit jantung koroner (PJK).

Metode. Penelitian potong lintang untuk mendeteksi risiko PJK dan peran indeks massa tubuh (IMT), masa lemak tubuh (MLT), leptin, adiponektin dan TNF- $\alpha$ terhadap risiko PJK pada anak lelaki obes prapubertal usia 5-9 tahun. Indeks massa tubuh ditentukan dengan menggunakan kurva CDC, massa lemak tubuh dihitung dengan alat body fat analyzer. Profil lipid, CRP, leptin, adiponektin, dan TNF- $\alpha$ diperiksa setelah subjek puasa selama 12 jam. Leptin, adiponektin, dan TNF- $\alpha$ diperiksa dengan cara ELISA.

Hasil. Seluruh subjek mempunyai IMT di atas nilai normal demikian pula MLT. Sebagian besar subjek mempunyai kadar TG, kolesterol total dan LDL meningkat dengan kadar kolesterol HDL menurun. Small dense LDL ditemukan pada sebagian kecil subjek. Kadar leptin dan TNF- $\alpha$ meningkat, sedangkan kadar adiponektin menurun. Hanya sebagian kecil subjek mengalami inflamasi kronik derajat rendah yang ditentukan dengan memeriksa CRP.

Kesimpulan. Risiko PJK telah tampak pada anak lelaki obes pra-pubertal. Indeks massa tubuh, MLT, leptin, adiponektin dan TNF- $\alpha$ tidak berhubungan dengan terjadinya sd LDL.
\end{abstract}

Sari Pediatri 2010;12(3):197-203.

Kata kunci: sdLDL, anak obes, risiko PJK, adipositokin

Alamat korespondensi:

DR. Dr. Aryono Hendarto, Sp.A(K). Divisi Nutrisi dan Penyakit Metabolik, Departemen IKA FK Universitas Indonesia/RS Dr. Cipto Mangunkusumo, Jakarta. Telp. 021-3915715/3910096.

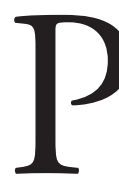

revalens obesitas pada anak meningkat baik di negara maju maupun di negara berkembang dalam dasawarsa terakhir. Namun demikian, apabila di negara maju akhir- 
akhir ini prevalens obesitas pada anak cenderung menurun karena upaya pencegahan yang dilakukan terus menerus, prevalens obesitas anak di Indonesia malahan bertambah banyak. ${ }^{1-3}$ Beberapa komorbiditas penyakit timbul sebagai dampak obesitas antara lain diabetes mellitus (DM) tipe II, penyakit jantung koroner (PJK), dislipidemia, asma, gangguan muskuloskleletal dan lain-lain. Penyakit jantung koroner merupakan salah satu penyakit yang paling banyak menyebabkan kematian. Beberapa faktor risiko terjadinya PJK telah diteliti pada individu dewasa antara lain meningkatnya kadar kolesterol LDL, rendahnya kadar kolesterol HDL, hipertensi, DM tipe I dan II, merokok dan obesitas. ${ }^{4}$ Penelitian pada anak dan remaja menunjukkan sebagian faktor risiko PJR telah timbul sejak usia muda. ${ }^{5,6}$ Kolesterol LDL merupakan faktor risiko aterosklerosis yang paling penting khususnya pada PJK. Namun demikian, PJK sering terjadi pada individu dengan kadar kolesterol LDL normal. Hal ini menunjukkan bukan hanya jumlah koleterol LDL, tetapi juga kualitas kolesterol LDL yang berperan sebagai faktor risiko PJK. Small dense LDL adalah salah satu jenis kolesterol LDL yang merupakan faktor risiko terhadap PJK. Individu yang mempunyai sdLDL akan menghadapi risiko PJK tiga kali lebih besar untuk mengalami PJK dibandingkan dengan individu tanpa sdLDL. ${ }^{7}$

Penelitian bertujuan untuk mengetahui faktor risiko terhadap PJK dengan mendeteksi adanya sdLDL pada anak obes pra-pubertal serta faktor yang mempengaruhi terjadinya sd LDL.

\section{Metode}

Penelitian merupakan studi potong lintang analitik untuk mencari hubungan antara sd LDL dengan indeks massa tubuh (IMT), massa lemak tubuh (MLT) dan adipositokin (leptin, adiponektin \& TNF- $\alpha$ ) pada anak pra-pubertas yang mengalami superobes. Penelitian dilakukan di poliklinik swadana Departemen Ilmu Kesehatan Anak (IKA) Fakultas Kedokteran Universitas Indonesia (FKUI)RS Dr. Cipto Mangunkusumo (RSCM), poliklinik rawat jalan rumah sakit ibu dan anak (RSIA) swasta di Jakarta Timur dan RSIA swasta Bekasi BaratJawa Barat, serta poliklinik unit kesehatan sekolah (UKS) sekolah dasar (SD) negeri Besuki-Jakarta Pusat. Penelitian dilakukan sejak bulan Maret 2007 sampai dengan Januari 2008. Obesitas ditentukan berdasarkan IMT menggunakan kurva CDC 2000. Anak dikategorikan superobes bila IMT berada di atas $P_{97}$ kurva IMR CDC 2000. Kriteria inklusi adalah anak lelaki superobes berusia 5-9 tahun, dan obesitas disebabkan faktor eksogen yang dibuktikan dengan asupan makanan berlebihan berdasarkan analisis diet. Subjek mempunyai corak pertumbuhan normal dan berdomisili di Jakarta dan sekitar Bekasi Barat. Kriteria eksklusi adalah anak yang sudah memasuki masa pubertas, obesitas disebabkan kelainan genetik/ kromosom atau sindrom (obesitas endogen) yang ditentukan berdasarkan pemeriksaan fisis, sedang mengonsumsi obat steroid, sitostatik atau obat lain yang memengaruhi berat badan (BB), sedang menjalani program diet untuk mengendalikan berat badan, sedang menderita penyakit infeksi akut dan orangtua/wali tidak bersedia ikut dalam penelitian. Indeks massa tubuh ditentukan dengan membagi BB (kg) dengan tinggi badan (TB) kuadrat $\left(\mathrm{cm}^{2}\right)$, sedangkan MLT adalah massa lemak tubuh total subjek yang ditentukan dengan menggunakan Tanita Inner Scan Body Composition Monitor tipe BC-545. Small dense LDL dihitung dengan membagi kadar LDL kolesterol dengan kadar Apo B. Pemeriksaan kadar kolesterol LDL dan Apo B dilakukan setelah subjek berpuasa selama 12 jam. Subjek dikatakan mempunyai sdLDL bila rasio antara kolsterol LDL/apo $B<1,2$. Pemeriksaan adipositokin yaitu leptin, adiponektin, dan TNF- $\alpha$ dilakukan dengan cara ELISA setelah subjek berpuasa selama 12 jam. Oleh karena belum tersedia nilai normal untuk titik potong (cut of point) MLT dan adipositokin (leptin, adipostokin, dan TNF- $\alpha$ ), maka titik potong untuk nilai-nilai tersebut ditentukan menurut kepustakaan luar negeri setelah dilakukan penyesuaian dengan memperhatikan profil subjek. Hubungan antar variabel diuji dengan analisis bivariat (Mann Whitney) dan analisis multivariat (regresi logistik) untuk mengetahui peran masingmasing variabel bebas terhadap variabel tergantung. Besar subjek dihitung dengan menggunakan rule of tumb yaitu jumlah variabel bebas dikalikan dengan 10-15 sehingga dibutuhkan sebanyak 50-75 subjek. Penelitian telah mendapat persetujuan dari Komite Etik Penelitian Fakultas Kedokteran Universitas Indonesia/RS. Dr.Cipto Mangunkusumo. Data diolah dan disajikan dengan menggunakan program SPSS for windows versi 17. 


\section{Hasil}

Didapatkan 72 anak lelaki prapubertas usia 5-9 tahun bersedia ikut dalam penelitian dengan rerata usia subjek 7 tahun 1 bulan. Seluruh subjek mempunyai status pubertas Tanner 1 yang berarti termasuk dalam masa pra-pubertas. Sebagian besar subjek mempunyai IMT antara $18-25 \mathrm{~kg} / \mathrm{m}^{2}$, sedangkan sisanya mem-

Tabel 1. Karakteristik subjek $(\mathrm{n}=72)$

\begin{tabular}{ccc}
\hline Karakteristik & $\mathrm{n}$ & $\%$ \\
\hline Usia (tahun) & & \\
5 & 20 & 28 \\
6 & 12 & 17 \\
7 & 19 & 26 \\
8 & 16 & 22 \\
9 & 5 & 7 \\
IMT $^{*}$ & & \\
$18-24,9$ & 40 & 56 \\
$25-29$ & 22 & 30 \\
$>30$ & 10 & 14 \\
MLT $^{* *}$ & & \\
$\leq 30$ & 17 & 24 \\
$>30$ & 55 & 76 \\
\hline
\end{tabular}

${ }^{*} \mathrm{IMT}=$ indeks massa tubuh, ${ }^{* *} \mathrm{MLT}=$ massa lemak tubuh

Tabel 2. Sebaran subjek menurut profil lipid $(n=72)$

\begin{tabular}{lcc}
\hline Profil lipid & $\mathrm{n}$ & $\%$ \\
\hline Kolesterol total & & \\
$\quad$ Normal & 36 & 50 \\
$\quad$ Borderline & 22 & 31 \\
$\quad$ Tinggi & 14 & 19 \\
HDL & & \\
$\quad$ Normal & 7 & 10 \\
$\quad$ Rendah & 65 & 90 \\
LDL & & \\
$\quad$ Normal & 31 & 43 \\
$\quad$ Borderline & 17 & 24 \\
$\quad$ Tinggi & 24 & 33 \\
Trigliserida & & \\
$\quad$ Normal & 11 & 15 \\
$\quad$ Tinggi & 61 & 85 \\
Apo B & & \\
$\quad$ Normal & 14 & 19 \\
$\quad$ Tinggi & 58 & 81 \\
sdLDL & & \\
$\quad$ Ya & 8 & 11 \\
$\quad$ Tidak & 64 & 89 \\
\hline
\end{tabular}

punyai IMT antara $25-30 \mathrm{~kg} / \mathrm{m}^{2}$ dan di atas $30 \mathrm{~kg} /$ $\mathrm{m}^{2}$. Indeks massa tubuh terkecil adalah $19 \mathrm{~kg} / \mathrm{m}^{2}$ dan terbesar adalah $40 \mathrm{~kg} / \mathrm{m}^{2}$ dengan rerata IMT 25 (SB 4) $\mathrm{kg} / \mathrm{m}^{2}$. Sebaran IMT subjek seluruhnya berada di atas $\mathrm{P}_{97}$ kurva IMT CDC 2000, yang berarti seluruh subjek termasuk kategori superobes. Sebaran MLT menunjukkan seluruh subjek mempunyai presentase IMT dengan nilai terendah $22,2 \%$ dan tertinggi $63 \%$, dengan rerata 35 (SB 7)\%.

Jumlah subjek yang mempunyai kolesterol total normal sama dengan jumlah subjek yang mempunyai kadar kolesterol total borderline dan tinggi. Sebagian besar subjek mempunyai kadar kolesterol HDL rendah, dan kadar kolesterol LDL borderline atau tinggi. Sebagian besar subjek mempunyai kadar trigleserida dan Apo B tinggi. Small dense LDL ditemukan pada $11 \%$ subjek (Tabel 2).

Kadar leptin total terendah adalah $6 \mathrm{ng} / \mathrm{dL}$ dan tertinggi $62 \mathrm{ng} / \mathrm{dL}$ dengan rerata 20 (SB 11) ng/dL. Kelompok umur 5 tahun mempunyai kadar leptin paling rendah $6 \mathrm{ng} / \mathrm{dL}$ dan tertinggi $45 \mathrm{ng} / \mathrm{dL}$ dengan rerata 20 (SB 10) ng/dL. Kelompok umur 6 tahun mempunyai kadar leptin terendah $6 \mathrm{ng} / \mathrm{dL}$ dan tertinggi $38 \mu \mathrm{g} / \mathrm{dL}$ dengan rerata 19 (SB 9) ng/dL. Kelompok umur 7 tahun mempunyai kadar leptin terendah $6 \mathrm{ng} /$ dL dan tertinggi $62 \mathrm{ng} / \mathrm{dL}$ dengan rerata 24 (SB 14) ng/ dL. Kelompok umur 8 tahun mempunyai kadar leptin terendah $6 \mathrm{ng} / \mathrm{dL}$ dan tertinggi $32 \mu \mathrm{g} / \mathrm{dL}$ dengan rerata 17 (SB 8) ng/dL. Kelompok umur 9 tahun mempunyai kadar leptin terendah $11 \mathrm{ng} / \mathrm{dL}$ dan tertinggi $42 \mathrm{ng} /$ dL dengan rerata 25 (SB 10) ng/dL. Sebagian besar subjek pada penelitian ini (61\%) mempunyai kadar leptin tinggi (hiperleptinemia), sedangkan sisanya mempunyai kadar leptin normal (normoleptinemia). Kadar adiponektin subjek mempunyai rentang antara 3-35 pg/dL dengan median $5 \mathrm{pg} / \mathrm{dL}$. Sebanyak 66 subjek (92\%) mempunyai kadar adiponektin rendah dan sisanya 6 pasien $(8 \%)$ mempunyai kadar adiponektin normal. Kadar TNF- $\alpha$ subjek mempunyai rentang antara 2-8 $\mu \mathrm{g} / \mathrm{dL}$ dengan median $3 \mu \mathrm{g} / \mathrm{dL}$. Jumlah subjek yang mempunyai kadar TNF- $\alpha$ tinggi dua kali lipat dibandingkan jumlah subjek yang mempunyai kadar TNF- $\alpha$ normal. Hasil pemeriksaan CRP untuk melihat apakah sudah terjadi proses inflamasi derajat rendah menunjukkan hanya sebagian kecil subjek yang sudah mengalami proses tersebut (Tabel 3).

Hasil analisis bivariat menunjukkan tidak ada hubungan antara sdLDL dengan IMT $(\mathrm{p}=0,097$, IK $0,087 ; 0,098)$, MLT $(\mathrm{p}=0,610)$, leptin $(\mathrm{p}=0,286$, IK 
Aryono Hendarto: Small dense low density lipoprotein sebagai prediktor risiko penyakit jantung koroner pada anak lelaki obes pra-pubertal

Tabel 3. Kadar adipositokin menurut adanya sdLDL $(\mathrm{n}=72)$

\begin{tabular}{|c|c|c|c|c|c|}
\hline \multirow{2}{*}{ Kadar adipositokin } & \multicolumn{4}{|c|}{ sd LDL } & \multirow{2}{*}{ Jumlah } \\
\hline & $\mathrm{Ya}$ & $\%$ & Tidak & $\%$ & \\
\hline \multicolumn{6}{|l|}{ Leptin } \\
\hline Normal & 1 & 4 & 27 & 96 & $28(100)$ \\
\hline Tinggi & 7 & 16 & 37 & 84 & $44(100)$ \\
\hline \multicolumn{6}{|l|}{ Adiponektin } \\
\hline Normal & 2 & 33 & 4 & 67 & $6(100)$ \\
\hline Rendah & 6 & 9 & 60 & 91 & $66(100)$ \\
\hline \multicolumn{6}{|l|}{ TNF- $\alpha$} \\
\hline Normal & 1 & 4 & 23 & 96 & $24(100)$ \\
\hline Tinggi & 7 & 15 & 41 & 85 & $48(100)$ \\
\hline \multicolumn{6}{|l|}{ hsCRP } \\
\hline Normal & 5 & 8 & 58 & 92 & $63(100)$ \\
\hline Tinggi & 3 & 33 & 6 & 67 & $9(100)$ \\
\hline
\end{tabular}

Tabel 4. Hasil analisis regresi logistik terhadap IMT, MLT, leptin, adiponektin, dan TNF- $\alpha$

\begin{tabular}{lcccccc}
\hline & Beta & Std Error & Wald & df & $p$ & Exp (B) \\
\hline IMT & $-0,139$ & 0,006 & $-1,053$ & 1 & 0,296 & $-0,006$ \\
MLT & 0,048 & 0,049 & 0,373 & 1 & 0,711 & 0,018 \\
Leptin & $-0,119$ & 0,002 & $-0,926$ & 1 & 0,358 & $-0,002$ \\
Adiponektin & $-0,083$ & 0,004 & 0,004 & 1 & 0,513 & $-0,003$ \\
TNF- $\alpha$ & $-0,106$ & 0,000 & 0,000 & 1 & 0,396 & $-1,3 \mathrm{E}-005$ \\
\hline
\end{tabular}

$0,292 ; 0,310)$, adiponektin ( $\mathrm{p}=0,463$, IK 0,$473 ; 0,492)$, dan TNF- $\alpha(p=0,286$, IK 0,289;0,307). Walaupun hasil analisis bivariat menunjukkan tidak satupun variabel bebas berhubungan dengan variabel tergantung, tetapi analisis multivariat tetap dilakukan untuk kelima variabel bebas tersebut dengan tujuan untuk melihat peran atau kontribusi masing-masing variabel terhadap terjadinya sdLDL (Tabel 4).

Dari hasil analisis multivariat menggunakan regresi logistik menunjukkan tidak satupun dari kelima variabel bebas yaitu IMR, MLT, leptin, adiponektin, dan TNF- $\alpha$ yang berhubungan dengan terjadinya sdLDL.

\section{Pembahasan}

Beberapa mekanisme telah dikemukakan tentang bagaimana cara terjadinya sdLDL. Peningkatan kadar serum trigliserida diketahui berhubungan erat dengan pembentukan sdLDL. Very low density lipoprotein ukuran besar dilepaskan ke dalam darah dan dimodifikasi untuk memproduksi sdLDL. Teori lain menyatakan terdapat dua pool di dalam darah, masing-masing dengan kecepatan metabolik berbeda dalam mengubah VLDL ke LDL. Pada keadaan hipertrigliseridemia, katabolisme VLDL ukuran besar terjadi di dalam pool yang ditandai dengan klirens darah yang lambat dan dengan mudah membentuk sdLDL. Penelitian lain melaporkan bahwa pada keadaan hipertrigliseridemia, trigliserida yang berada di dalam VLDL akan ditransfer ke HDL, selanjutnya HDL yang kaya akan trigliserida (TG) memberikan TG kepada LDL dan mengekstraksi kolesterol yang selanjutnya akan terbentuk sdLDL. Apakah hiper trigliserida (TG) post prandial atau puasa yang lebih berhubungan dengan penurunan ukuran LDL masih belum jelas. Namun penelitian menunjukkan subjek dengan trigliserida (TG) puasa normal memperlihatkan hubungan antara ukuran LDL dengan TG puasa sangat lemah. Pada keadaan hiper trigliserida (TG) setelah diberikan makanan fat load sangat berkorelasi dengan ukuran LDL. Data tersebut memberikan dugaan bahwa kadar trigliserida (TG) post prandial lebih berperan terhadap ukuran LDL pada subjek dengan kadar lipid normal. ${ }^{8}$ 
Sebagian besar subjek mengalami peningkatan kadar trigliserida (TG) puasa, sehingga seharusnya jumlah subjek yang mempunyai sdLDL lebih banyak dan variabel bebas yang diuji berhubungan dengan terjadinya sdLDL. Ternyata bukan hanya trigliserida (TG) yang berperan atas terjadinya sdLDL. Kolesterol HDL terutama fraksi Apo A-1 juga memegang peran penting terhadap pembentukan sdLDL. Bahkan pada beberapa penelitian, rasio antara Apo B dengan Apo A-1 juga telah terbukti dapat digunakan sebagai prediktor risiko PJK. Jenis diet juga berpengaruh terhadap pembentukan sdLDL. Penelitian menunjukkan bahwa asupan tinggi fruktosa akan meningkatkan kadar sdLDL di dalam darah. ${ }^{9}$ Jenis lemak yang dikonsumsi juga berperan, dan telah diketahui asupan lemak jenis trans akan meningkatkan kadar sdLDL. ${ }^{10}$

Tidak adanya hubungan antara IMT dengan sdLDL mungkin disebabkan karena perbedaan deposit lemak antara individu dewasa dan anak. Pada dewasa, penumpukan lemak lebih banyak terjadi pada bagian tubuh tengah ke bawah sedangkan pada anak-anak cenderung pada bagian tubuh sebelah atas. Di samping itu sensitivitas IMT sebagai alat untuk memperkirakan MLT masih dipertanyakan, walaupun beberapa pakar sepakat pada saat ini bahwa IMT masih relevan digunakan sebagai alat prediksi MLT pada obesitas. ${ }^{8,11}$

Penelitian menunjukkan anak yang mempunyai MLT $>33 \%$ akan mempunyai risiko terhadap penyakit kardio vaskular. ${ }^{12}$ Pada penelitian kami tidak adanya hubungan antara MLT dengan risiko PJK disebabkan karena beberapa hal. Jaringan adiposa mempunyai fungsi utama yaitu sebagai jaringan yang dapat menyimpan energi dan melepaskannya dalam bentuk asam lemak bebas bila dibutuhkan oleh tubuh. Jaringan adiposa berperan penting dalam patogenesis resisten insulin, DM tipe 2, sindrom metabolik, dan PJK melalui produk yang dihasilkan oleh jaringan yang disebut dengan adipositokin. Beberapa adipositokin yang berperan antara lain leptin adiponektin, resistin, TNF- dan masih banyak lagi. Adipositokin tersebut bersifat sebagai anti inflamasi dan ada pula yang proinflamasi. Apabila jaringan adiposa masih memproduksi adipositokin yang berfungsi normal maka komorbiditas akibat obesitas belum akan muncul. Penyebab lain tidak adanya hubungan antara MLT dan sdLDL adalah cara penentuan MLT. Pada penelitian kami digunakan body fat analyzer, sedangkan pemeriksaan yang diyakini lebih akurat adalah menggunakan dual energy $x$ ray absorptiometry (DEXA). ${ }^{13}$ Faktor lain adalah peran lingkaran pinggang. Penelitian menunjukkan kombinasi MLT dan lingkaran pinggang merupakan parameter yang lebih baik untuk memprediksi risiko PJK dibandingkan hanya MLT saja. ${ }^{12}$

Leptin berperan pada metabolisme lemak yang mekanisme pengaturannya tanpa melalui hipotalamus. Suplementasi leptin dapat menstimulasi lipolisis dan menghambat lipogenesis. Peningkatan kadar leptin dalam sirkulasi dapat menurunkan kadar lemak di berbagai jaringan melalui peningkatan oksidasi lemak. Selain itu leptin juga berperan dalam meningkatkan aktivitas hormon sensitif lipase (HSL) yang terlibat dalam pemecahan kolesterol ester di makrofag. Gangguan pada pengaturan HSL dapat menjadi awal untuk terjadinya sel busa yang akan menyebabkan terjadinya aterosklerosis. ${ }^{14,15}$ Pada penelitian kami, sebagian besar subjek mengalami hiperleptinemia seperti yang ditemukan pada individu dewasa obes. Pada dewasa obes keadaan hiperleptinemia ini berarti terjadi resitensi leptin, dengan demikian kemampuan leptin untuk berperan dalam metabolisme lemak terganggu. Dengan demikian seharusnya terdapat hubungan antara leptin dengan risiko PJK.

Demikian pula dengan adiponektin suatu adipositokin yang secara eksklusif dihasilkan oleh sel adiposa. Adiponektin akan berikatan dengan kolagen I, II, dan V yang merupakan komponen utama tunika intima pembuluh darah yang akan terakumulasi pada dinding vaskular bila barier endotel mengalami kerusakan. Pada subjek yang mengalami PJK, kadar adiponektin ini akan menurun. Adiponektin juga dikenal sebagai adipositokin anti inflamasi karena perannya yang dapat menghambat sekresi adipositokin pro inflamasi seperti TNF- $\alpha$ dan interleukin 6 (IL6). Di pihak lain karena fungsinya sebagai adipositokin anti inflamasi, maka adiponektin berperan sebagai anti aterogenik. ${ }^{16,17}$ Penelitian menunjukkan subjek yang mempunyai kadar adiponektin rendah akan menghasilkan sd LDL yang meningkat sehingga berisiko terjadinya PJK. ${ }^{18}$

Meningkatnya kadar TNF- $\alpha$ pada sebagian besar subjek sama seperti yang ditemukan pada dewasa obes. Adipositokin ini dikenal sebagai adipositokin pro inflamasi karena kadarnya ditemukan meningkat pada individu obes dan berkaitan dengan komorbiditas yang timbul akibat obesitas. Dengan demikian seharusnya terdapat hubungan antara meningkatnya TNFdengan terbentuknya sdLDL. 
Sebagian besar subjek mempunyai profil adipositokin seperti individu dewasa obes yaitu meningkatnya kadar leptin dan TNF- $\alpha$ yang disertai dengan menurunnya kadar adiponektin. Namun demikian karena hanya sedikit subjek yang jaringan adiposanya mengalami proses inflamasi kronik derajat rendah yang dapat dilihat dari masih normalnya kadar CRP pada sebagian besar subjek. Penelitian menunjukkan CRP selain untuk mengidentifikasi adanya infeksi akut, juga dapat digunakan untuk memprediksi adanya proses inflamasi derajat rendah. ${ }^{19}$ Sebagian besar jaringan adiposa belum mengalami inflamasi kronik derajat rendah, maka pada jaringan adiposa masih terjadi kesimbangan antara adipositokin anti inflamasi dan pro inflamasi. Hal ini berarti sebagian besar jaringan adiposa masih memproduksi adipositokin yang berfungsi normal. ${ }^{20}$ Juga menerangkan mengapa tidak terjadi hubungan antara leptin, adiponektin dan TNF- $\alpha$ dengan sdLDL. Peran adipositokin selain ketiga adipositokin tersebut perlu juga dipertimbangkan, karena sampai saat ini berbagai jenis adipositokin telah diketahui diproduksi oleh jaringan adiposa. ${ }^{21}$ Oleh karena itu diperlukan penelitian lebih lanjut untuk mengetahui seberapa jauh risiko PJK telah mengancam obesitas pada anak. Penelitian tersebut selain bertujuan untuk mengeksplorasi peran adipositokin lain, juga penting melakukan penelitian pada kelompok usia balita dan remaja.

Dari penelitian kami, disimpulkan pada anak lelaki pra pubertas usia 5-9 tahun yang mengalami obesitas, walaupun hanya ditemukan pada sejumlah kecil subjek, namun risiko penyakit jantung koroner telah terlihat dengan ditemukannya sd LDL. Terjadinya sdLDL pada kelompok pra-pubertas tidak berhubungan dengan indeks massa tubuh, massa lemak tubuh, leptin, adiponektin dan TNF- $\alpha$. Diperlukan penelitian lanjutan untuk mengetahui berapa besar risiko PJK pada anak yang mengalami obes di setiap kelompok usia, jenis kelamin, dan peran adipositokin lain terhadap risiko penyakit jantung koroner.

\section{Daftar pustaka}

1. Must A, Spadano J, Coakley EH, Filed AE, Coldditz G, Dietz WH. The disease burden associated with overweight and obesity. JAMA 1999;282:1523-9.

2. Roth J, Qiang X, Marban SL, Redelt H, Lowell BC. The obesity pandemic: Where have we been and where are we going?. Obes Res 2004;12:88S-101S.
3. Sjarif DR. Penelitian multi senter obesitas anak di Indonesia. Dipresentasikan dalam Kongres Nasional Ilmu Kesehatan Anak. Bandung: 2005.

4. Ross R. The pathogenesis of atherosclerosis: An update. N Engl J Med 1986;31:488-500.

5. Wilcox I. Cadiovascular consequences of obesity. Dalam: Kopelman PG, Caterson ID, Dietz WH, penyunting. Clinical obesity in adults and children. Edisi ke-3. London: Blackwell; 2010.h.392-408.

6. Daniels SR, Greer FR. Lipid screening and cardiovascular health in childhood. Pedaitrics 2008;122:198-208.

7. Hirano T, Yoshino G. Small dense LDL. Progress Med 1999; 19:1854-9.

8. Higgins PB, Gower BA, Hunter GR, Michael I. Goran MI. Defining health related obesity in prepubertal children. Obes research 2001;4:223-40.

9. Shanhope KL, Sawartz JM, Keim NL, Griffen SC, Bremer AA, Graham JL, dkk. Effect of consuming fructose or glucose sweetened beverages for 10 weeks on lipids, insulin sensitivity and adiposity. J Clin Invest 2009; 119:1322-34.

10. Vega Lopes S, Matthan NR, Ausman LM, Ai M, Otokozawa S, Shaefer EJ, dkk. Substitution of vegetable oil for a partially hydrogenated fat favorably alters cardiovascular risk factors in moderately hypercholesterolemic post menopausal women. Atherosclerosis 2009;207:208-12.

11. Weisell RC. Body mass index as an indicator of obesity. Asia Pacific J Clin Nutr 2002;11:S6814.

12. Daniels SR, Morrison JA, Sprecher DJ, Khoury P; Kimball TR. Association of body fat distribution and cardiovascular risk factors in children and adolescents. Circulation 1999;99:541-5.

13. Lindsay RS, Hanson RL, Roumain J, Ravussin E, Knowler WC, Tataranni PA. Body mass index as a measure of adiposity in children and adolescents: Relationship to adiposity by dual energy $\mathrm{x}$ ray absorptiometry and to cardiovascular risk factors. J Clin Endocrinol Metab 2001;86:4061-7.

14. Rourke L, Yeaman S, Sheperd P. Insulin and leptin acutely regulate cholesterol ester metabolism in macrophages by novel signaling pathways. Diabetes 2001;50:955-961.

15. Escary JL, Choy HA, Reue K, Schotz MC. Hormon sensitive lipase over expresion increase cholesteryol ester hydrolisis in macrophage foam cells. Atherioscler Thromb Vasc Biol 1998;18:991-8.

16. Ouchi N, Kihara S, Arita Y, Okamoto Y, Maeda K, Kuriyama H, dkk. Adiponectin, an adipocyte derived plasma protein, inhibits endothelial NF-kB signaling 
through a cAMP dependent pathway. Circulation 2000;102:1296-301.

17. Hotta K, Funahashi T, Arita Y, Yahashi M, Matsuda M, Okamoto Y, dkk. Concentration of a novel adipose specific protein, adiponectin, in type 2 diabetic patients. AteriosclerThromb Vasc Biol 2000;20:1595-9.

18. Weiss R, Frystyk J, Otvos JD, Sinnreich RS, Flyvbjerk A, Kark JD, dkk. Adiponectin and lipoprotein particle size. Diabetes Care 2009;32:1317-9.
19. Santos AC, Lopes C, Guimaraes JT, Barros H. Central obesity as a major determinant of increased high sensitivity $\mathrm{C}$ reactive protein in metabolic syndrome. Int J Obes 2005;29:1452-6.

20. Sethy JK, Vidal-Puig AJ. Adipose tissue function and plasticity orchestrate nutritional adaptation. J Lipid Res. 2007;48:1253-62.

21. Kershaw EE, Flier JS, Adipose tissue as an endocrine organ. J Clin Endocrinol Metab 2004;89:2548-56. 